\title{
The Characteristics Of A Good ODL Practitioner
}

Michael C. Cant, University of South Africa, South Africa Johannes A. Wiid, University of South Africa, South Africa Ricardo Machado, University of South Africa, South Africa

\begin{abstract}
Much has been said as to what makes a good Open and Distance Learning (ODL) practitioner or lecturer if you prefer. It is easy to make statements and observations, but it is, however, essential to establish exactly what an ODL practitioner is and then to establish if there is a set of characteristics that can be attached to such a practitioner. That, in essence, is the main aim of this study; namely, to investigate the characteristics of a good ODL practitioner. With the increase in student numbers at ODL institutions, there is a need for an increased number of ODL practitioners who are able to provide the quality education that the ODL students desire or need (Roberts, n.d.:1). In order to satisfy the objectives of the study, a self-administered survey was distributed to the ODL practitioners within an ODL institute. The results of this study revealed that there is a difference as to what these respondents saw in terms of the relevant importance of some characteristics. It is evident from the results that an ODL practitioner should have good subject knowledge, and should be fair and ethical.
\end{abstract}

Keywords: ODL Practitioners; Practitioner Characteristics; ODL Institution; Distance Learning; Education Challenges

\section{INTRODUCTION}

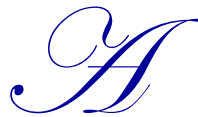

$\mathrm{s}$ is the case in all businesses and life, one needs to find the correct balance in order to be efficient and effective in what you do. This is especially true in today's educational environment where there are greater demands placed on educators from the student body to not only divulge knowledge but to also do it in such a way that the student body or learner, with their own set of skills and demands, can receive this knowledge in a meaningful and applicable manner. The rationale for this study aims to match, as far as possible, the characteristics of the practitioner to what is required by the student. With reference to the above, one can state that in an academic institution, the correct types of lecturers with the correct set of skills are needed to meet and achieve the objectives of the institution.

In order to understand the dynamics of ODL and the characteristics of an ODL practitioner, one would require an effective and complete understanding of the educational system, including what the ODL student requires. ODL (open and distance learning) can be defined as a learning situation where the student is geographically separated from the practitioner or lecturer (here forth referred to as ODL practitioner) which, in itself, offers challenges to the institution when it comes to parting with knowledge and skills. It is often assumed that a good ODL practitioner will possess the same, or similar, characteristics as a good lecturer at a residential university. In the case of an ODL institution, as opposed to the practitioner or lecturer in a classroom or residential university, different types of characteristics may be required in order to effectively tutor the respective students. According to London Deanery (2012), these may include exhibiting expert knowledge in their subject field, ensuring that study sections or blocks are paced correctly to make progress possible, the provision of relevant, positive and constructive criticism and feedback, illustrating the practical applications of the theory they present, and showing enthusiasm for and generating curiosity about the subject matter. On the other hand, there will most likely be additional characteristics of each of these two practitioners that cater more specifically for the specific needs of their students who operate in different environments, viz. residential and geographically spread. 
The importance and relevance of open distance learning and affiliated ODL practitioners have taken on new relevance in the past number of years. This is due to the worldwide economic slowdown since 2008 and the renewed belief by many, especially in third world countries, that education will lead to better job prospects. It is a known fact that when the economy slows down, people use the time to improve their skills and educate themselves. Many traditional residential universities have also embarked on extending their offering to include limited ODL tuition, once again emphasising the need to make sure what the characteristics of a good ODL practitioner should be. It is also noted that the open distance learning model bridges many gaps that would have otherwise made it difficult for students to reach their educational goals. These gaps can and should not be measured only in the way that technology can be used. Technology will always form an integral part of the tuition model and with the advances taking place at such a rapid pace, all institutions need to incorporate these technologies (where relevant) in their tuition model, but the human element should not be forgotten. This means being able to work with students in such a way that a caring and knowledgeable partaking attitude is portrayed. Therefore, ODL practitioners need to have the necessary characteristics and skills to facilitate the process of learning at an open distance learning university. This poses additional questions with regard to the total product offering (or learning experience) which includes student service and support that students receive from ODL practitioners:

$\bullet$

Are ODL practitioners able to provide the feedback and the support that the students require?

- What characteristics do the ODL practitioners need to have that will result in them being considered a good ODL practitioner?

Based on the views and discussion above, the aim of this study is to investigate the characteristics that a good ODL practitioner should possess, as perceived by the practitioners themselves. The next section will delineate the research aim and objectives that need to be satisfied. Thereafter, a literature review will be conducted on previous research concerning this topic, followed by the research methodology used. The paper will conclude with the research findings, limitations, recommendations, and the conclusion.

\section{LITERATURE REVIEW}

The quality of ODL practitioners plays an important role in the provision of high-quality education at any institution and refers directly to the teaching staff who, for all practical purposes, are the main contributors to a teaching institution (Gruber et al., 2010:178). By implication this means that the characteristics an ODL practitioner possesses, including their behaviour and attitude, will have an effect on the level of satisfaction students will have during their interaction with higher education.

\section{The Changing Tuition Landscape in Education}

In general, universities are often seen as traditional educational institutions that are resistant to change and where academic freedom reigns supreme (Lovitt, n.d.; Ekroth, n.d.). There may be many reasons for this resistance but these are now becoming less relevant and sustainable with the rapid growth and development taking place in the technological, cultural, and global sectors of the environment. This resistance to change needs to make place for the current demands of the student. Universities have shown the ability to adapt to better meet the needs of students and society and in order to survive, they will need to keep on adapting (Lovitt, n.d.). The changing needs and demands of the industry and the emphasis on skills and applicability are forcing universities to change the content and approach of their offerings in response to emerging environmental pressures and market preferences. Lecturers at higher learning institutions are now not only expected to cover the curriculum, but also to equip and enable students to think critically, write skilfully, and speak competently (Ekroth, n.d.). "Universities' ability to reinvent themselves proves that they have the flexibility and commitment to remain relevant in a world in which change is the only constant; a key indication of the change that is taking place in universities is the revitalised attention to student learning" (Lovitt, n.d.). Some of the major changes that universities are facing (Maslen, 2012) are trends, such as the democratisation of knowledge as a result of the spreading of online resources, the use of technology to deliver programmes and courses, the increased offering of so called online courses, the fact that learning is not geographically limited or focussed but rather global, and the integration with industry to make training more relevant. 
The landscape of tuition is further complicated by the huge growth in student numbers. According to The International Education Association of South Africa (IEASA, n.d.), South African student enrolments have grown at approximately $6.2 \%$ per year since the year 2000 . This, however, does not only mean the numbers are changing, but also the demands of these students. A survey conducted in 2012 indicated that $57 \%$ of students want more open educational resources (ICEF, 2012) which may point to a search for more meaning and detail, as well as the fact that students want to broaden experiences and exposure. These demands and changes will have an impact on the offerings of universities, as well as the way these are offered, and, by implication, impact on what characteristics a good ODL practitioner should have.

\section{Defining ODL}

The definition of distance learning must be understood in order to grasp the content of this study. "At its most basic level, distance education takes place when a teacher and student(s) are separated by physical distance, and technology (i.e., voice, video, data, and print), often in collaboration with face-to-face communication, is used to bridge the instructional gap" (Gottschalk, n.d.). The 'open' nature of distance learning refers to aspects such as policies of open admissions, and freedom of selection of what, when and where to learn (UNESCO, n.d.). The constant development in technology makes it possible for institutions to engage students in various ways by means of this technology. Distance education is therefore an integral part of education and has even been embraced by residential universities in their quest to meet learner demands (Samans, n.d.).

An open distance learning model is therefore a student-centred approach whereby integrated systems and engaged learning takes place, with the aim of open distance learning being to bridge the time, space, economic, social, educational and communication distance between students and the institution, the ODL practitioners, courseware, and other students. The open distance learning model requires that the ODL practitioners provide a 'product offering' that is different than that of residence universities, and in order to do this, one would premise that the ODL practitioner will be required to have specific characteristics.

\section{Challenges Faced by ODL}

Given the fact that ODL students are geographically dispersed, ODL practitioners have to deal with numerous challenges if they are to provide meaningful and suitable tuition to these students. These challenges include teacher contact and feedback, student support and services, alienation and isolation, lack of experience, as well as demonstrations of practical applications (Galusha, 1998).

It can be assumed that a good ODL practitioner will exhibit characteristics that counteract these challenges, such as the ability to offer prompt and effective feedback, regular contact, and the ability to take advantage of the latest trends in technology as tools for distance education. ODL practitioners face a multitude of challenges when interacting with students, as they are not in a position where they have direct contact with the students as is the case with residential universities. This further implies that the composition of an ODL practitioner will be different from that of a residential university practitioner, which will require the use of different methods and means in order to teach. For example; with the change in the use of technology, ODL practitioners have moved from traditional models of teaching, which include information transmission and comprehension, toward more collaborative learning models where the ODL practitioner and student are able to perform a collaborative learning/teaching process $-\mathrm{a}$ process that is constantly evolving as well (Forsyth et al., 2010:23).

In addition to the challenges indicated above, the appointment of lecturers is also affected by the fact that ODL practitioners require different skills and have a different set of characteristics than lecturers at residential universities. Usually universities, when appointing new lecturers, have set a number of requirements for those positions. Applicants are required to have a variety of skills and qualities (Fiedler \& Welpe, 2008:6). There are a number of qualities that universities seek, such as publications in prestigious journals, high-quality conference contributions, taking risks in personal research (Hickman \& Shrader, 2000:93), didactical skills and committed teaching, personal competence, international experience, networking in the department in which one is applying, creativity and innovativeness, professional suitability, skilled in raising third-party research funds, practical experience and the willingness to take ownership toward academic self-management, amongst many others (Fiedler \& Welpe, 2008:6). All these requirements will still be applicable to the ODL practitioner as it forms the basis of 
what it means to be an academic, but it may also require other skills in order to be able to meet the demands of the ODL student.

\section{Background on the Characteristics of ODL Practitioners}

According to Ingram (2003) and Harper (2012), an ODL practitioner should be a leading expert in a specific field of study at a university. A number of authors have investigated the main characteristics of effective practitioners (Desai et al., 2001; Paswan \& Young, 2002; Smart et al., 2003). The characteristics noted most frequently include that they be knowledgeable, enthusiastic, reliable, helpful, and possess the relevant expertise, as reflected in Table 1.

Table 1: Characteristics of Effective Practitioners

\begin{tabular}{|l|l|}
\hline \multicolumn{1}{|c|}{ Authors } & \multicolumn{1}{c|}{ Characteristics of Effective Practitioners } \\
\hline McElwee \& Redman (1993) & Reliable: deliver on time and keep records of student performance \\
\hline Husbands (1998) and Pozo-Munoz et al. (2000) & Expertise \\
\hline Hill et al. (2003) & $\begin{array}{l}\text { Knowledgeable, well-organised, encouraging, helpful, sympathetic, and } \\
\text { caring to students' individual needs }\end{array}$ \\
\hline Brown (2004) & $\begin{array}{l}\text { Competent, approachable, willing to answer questions, show flexibility and } \\
\text { willing to explain things in different ways, treat their students as individuals }\end{array}$ \\
\hline Swanson, Frankel \& Slagan (2005) & $\begin{array}{l}\text { Knowledgeable, empathetic, friendly, helpful, reliable, responsive, and } \\
\text { expressive }\end{array}$ \\
\hline
\end{tabular}

Source adapted from: Gruber et al. (2010:179)

Characteristics, such as being approachable, friendly, receptive to student suggestions, possessing a sense of humour and enthusiasm, are major factors that relate to interactions that take place between the student and ODL practitioner. The "teaching skills", "expertise", "reliability" and "respect" that ODL practitioners exhibit are considered by students as compulsory. Although many of these characteristics are based on the perceptions of students, other characteristics, such as the ODL practitioner "being knowledgeable", is something students are not best equipped to judge due to the nature of the relationship of learner/teacher. Thus, it is best that certain characteristics, such as "being knowledgeable", be judged by the faculty themselves (Gruber et al., 2012:174).

\section{The Importance of ODL Practitioners Possessing the Correct Skills}

For any educational institution to be able to meet the demands of open distance learning, it is imperative that the practitioners chosen for ODL courses possess the correct set of skills and characteristics. Engaging and stimulating lectures, regardless of how technologies are used, are what really predict students' appreciation of a given university course (Charbonneau, 2012). These essential elements must be retained in the case of the ODL practitioner. Skills, such as flexibility and the ability to assume the role of a facilitator, will encourage autonomy among ODL students and teach them how to work for themselves (SWAP, 2008). Naturally, the skills and input of an ODL practitioner will affect the outcomes of the course, such as student satisfaction, student performance and results. By attracting practitioners with the right set of skills and characteristics, educational institutions help to increase the likelihood that they construct relevant and engaging courses of study (Ferrari, 2012). It can be concluded that the characteristics of a good ODL practitioner are crucial in the success of the ODL tuition model and that having a better understanding of these characteristics will greatly enhance the learning experience of the student in an ODL environment.

\section{PURPOSE OF STUDY}

The purpose of this study is to determine the characteristics that make a good ODL practitioner, from the viewpoint of ODL practitioners. Secondary objectives for the study are:

- $\quad$ to identify the important characteristics of a good ODL practitioner

- $\quad$ to investigate whether there are differences between different demographic categories in terms of their opinions of the characteristics of a good ODL practitioner

The methods that were used in order to obtain the relevant data are discussed in the next section. 


\section{METHODOLOGY}

The investigation first consists firstly of a literature study that deals with characteristics of lecturing staff at higher education institutions. The second part of the investigation is an empirical study which is directed primarily at lecturing staff at an ODL institution and has two phases. In the first phase, the most important success factors were identified by means of a Delphi technique from a list of possible characteristics of an ODL practitioner. The respondents who participated in this technique are lecturing staff at an ODL institution. A list of the characteristics that were identified as the most important by the Delphi technique are:

- $\quad$ Good writing skills

- $\quad$ Good subject knowledge

- Good practical knowledge base

- $\quad$ A student-centred orientation

- Technological savvy

- $\quad$ Good communication skills

- $\quad$ Ability to guide students

- $\quad$ Quality consciousness

- $\quad$ Ability to apply ODL principles

- $\quad$ Fair and ethical behaviour

In the second phase, only the characteristics that were identified as most important were included in the structured questionnaire. The respondents were lecturing staff at a major ODL institution in South Africa and they were asked to evaluate these characteristics on a 1-7 point Likert scale in terms of the degree of importance. A total of 204 usable responses were received.

\section{Demographic Profile of Respondents}

The demographic profile of the respondent group is presented in Table 2. The majority of the ODL practitioners $(26.40 \%)$ were between 26 and 35 years of age. The gender split for the respondent group is slightly more female $(55.33 \%)$, whereas the males were $44.67 \%$. Almost half of the respondents $(49.75 \%)$ were senior members of the lecturing staff.

The gender distribution is evenly distributed, except in the category of lecturers with 0-5 years' experience, where there are more females than males.

Table 2: Biographical Information

\begin{tabular}{|c|c|c|c|c|}
\hline \multirow[b]{2}{*}{ Department } & \multicolumn{2}{|l|}{ Male } & \multicolumn{2}{|c|}{ Female } \\
\hline & $\%$ of Total & $\mathbf{N}$ & \% of Total & $\mathbf{N}$ \\
\hline Business Management & $11.60 \%$ & 21 & $13.26 \%$ & 24 \\
\hline Marketing and Retail & $2.21 \%$ & 4 & $5.52 \%$ & 10 \\
\hline Finance, Risk Management and Banking & $11.60 \%$ & 21 & $9.39 \%$ & 17 \\
\hline Human Resource Management & $1.10 \%$ & 2 & $7.18 \%$ & 13 \\
\hline Industrial Psychology & $1.10 \%$ & 2 & $1.66 \%$ & 3 \\
\hline Public Administration & $4.97 \%$ & 9 & $0.55 \%$ & 1 \\
\hline Auditing & $3.87 \%$ & 7 & $2.21 \%$ & 4 \\
\hline Management Accounting & $4.42 \%$ & 8 & $7.18 \%$ & 13 \\
\hline Financial Accounting & $4.97 \%$ & 9 & $1.66 \%$ & 3 \\
\hline Tax & $1.66 \%$ & 3 & $3.87 \%$ & 7 \\
\hline Position & & & & \\
\hline Junior ODL practitioner & $1.54 \%$ & 3 & $2.56 \%$ & 5 \\
\hline ODL practitioner & $14.36 \%$ & 28 & $22.56 \%$ & 44 \\
\hline Senior ODL practitioner & $21.03 \%$ & 41 & $28.72 \%$ & 56 \\
\hline Associate ODL practitioner & $6.67 \%$ & 13 & $1.03 \%$ & 2 \\
\hline ODL practitioner & $1.03 \%$ & 2 & $0.51 \%$ & 1 \\
\hline
\end{tabular}


Table 2 cont.

\begin{tabular}{|c|c|c|c|c|}
\hline \multicolumn{5}{|c|}{ Years } \\
\hline $0<5$ & $27.92 \%$ & 55 & $40.61 \%$ & 80 \\
\hline $6-10$ & $3.55 \%$ & 7 & $6.60 \%$ & 13 \\
\hline $11-15$ & $5.08 \%$ & 10 & $3.55 \%$ & 7 \\
\hline $16-20$ & $1.52 \%$ & 3 & $2.03 \%$ & 4 \\
\hline $20>$ & $6.60 \%$ & 13 & $2.54 \%$ & 5 \\
\hline \multicolumn{5}{|c|}{ Age } \\
\hline$<25$ & $0.51 \%$ & 1 & $3.55 \%$ & 7 \\
\hline $26-30$ & $6.09 \%$ & 12 & $15.23 \%$ & 30 \\
\hline $31-35$ & $9.64 \%$ & 19 & $11.17 \%$ & 22 \\
\hline $36-40$ & $4.06 \%$ & 8 & $10.66 \%$ & 21 \\
\hline $41-45$ & $5.08 \%$ & 10 & $5.08 \%$ & 10 \\
\hline $46-50$ & $4.06 \%$ & 8 & $4.57 \%$ & 9 \\
\hline $51-55$ & $10.15 \%$ & 20 & $4.06 \%$ & 8 \\
\hline$>56$ & $5.08 \%$ & 10 & $1.02 \%$ & 2 \\
\hline \multicolumn{5}{|c|}{ Ethnic group } \\
\hline African & $20.41 \%$ & 40 & $9.18 \%$ & 18 \\
\hline Coloured & $0.51 \%$ & 1 & $2.04 \%$ & 4 \\
\hline Indian & $2.55 \%$ & 5 & $3.57 \%$ & 7 \\
\hline White & $21.43 \%$ & 42 & $40.31 \%$ & 79 \\
\hline \multicolumn{5}{|c|}{ Gender } \\
\hline Male & $44.67 \%$ & 88 & & \\
\hline Female & $55.33 \%$ & 109 & & \\
\hline
\end{tabular}

\section{Reliability}

A number of tests can be used to determine the internal consistency and repeatability of results in a survey. This is done by testing two different parts of the same instrument in a process that averages the correlation between every possible combination of questionnaire statements used in the study.

For a multi-item scale, such as the Likert used in this study, Cronbach's Alpha (a coefficient between 0 and 1) is used to test for internal consistency. A coefficient that is too low (below 0.7) shows that respondents most likely interpret the meaning of statements differently and a coefficient that is too high (above 0.9) could mean that it is likely that some statements used in the study are too similar and can be removed from the measuring instrument.

The sample of the study scored an overall Cronbach's Alpha of 0.9257, against the international norm for reliability using Cronbach's Alpha which is 0.7 .

This study can be described as having content validity as none of the items measured were difficult to define, and the probability is high that all respondents understood the statements in a uniform manner.

Table 3: Summary of Rankings for the 10 Statements

\begin{tabular}{|l|c|c|c|c|c|c|c|c|c|}
\hline $\mathbf{N r}$ & Statements & $\mathbf{1}$ & $\mathbf{2}$ & $\mathbf{3}$ & $\mathbf{4}$ & $\mathbf{5}$ & $\mathbf{6}$ & $\mathbf{7}$ & $\mathbf{M e a n}$ \\
\hline 1.1 & Good writing skills & 3 & 1 & 0 & 4 & 29 & 46 & 121 & 6.32 \\
\hline 1.2 & Good subject knowledge & 3 & 0 & 0 & 1 & 17 & 47 & 136 & 6.50 \\
\hline 1.3 & Good practical knowledge base & 3 & 2 & 0 & 13 & 44 & 75 & 67 & 5.87 \\
\hline 1.4 & Technologically savvy & 3 & 1 & 4 & 18 & 69 & 58 & 50 & 5.58 \\
\hline 1.5 & A student centred orientation & 3 & 0 & 3 & 10 & 37 & 70 & 81 & 6.00 \\
\hline 1.6 & Good communication skills & 3 & 1 & 1 & 2 & 24 & 65 & 108 & 6.28 \\
\hline 1.7 & Ability to guide students & 3 & 0 & 1 & 5 & 22 & 61 & 112 & 6.30 \\
\hline 1.8 & Quality consciousness & 3 & 0 & 0 & 7 & 17 & 74 & 103 & 6.28 \\
\hline 1.9 & Ability to apply ODL principles & 3 & 2 & 2 & 6 & 42 & 64 & 84 & 6.00 \\
\hline 1.10 & Fair and ethical behaviour & 3 & 0 & 0 & 7 & 20 & 48 & 126 & 6.38 \\
\hline
\end{tabular}


In order to determine the important characteristics of a good ODL practitioner, respondents were asked to rate 10 statements on a 7-point Likert scale where number 1 indicates "Strongly disagree" and number 7, "Strongly agree". These statements are illustrated in Table 3.

\section{RESULTS AND DISCUSSION}

Most respondents agreed or strongly agreed with the statements by choosing either 5,6 or 7 . This is also shown by the averages varying from 5.58 to 6.50 . All the characteristics were considered as important by the respondents. Considering the averages (for ranking purposes), "Good subject knowledge" (1.2) and "Fair and ethical behaviour" (1.10) are considered most important, with "Good writing skills" (1.1), "Ability to guide students" (1.7), "Good communication skills" (1.6), and "Quality consciousness" (1.8) considered less important.

Figure 1 produces a visual representation of the responses towards the characteristics.

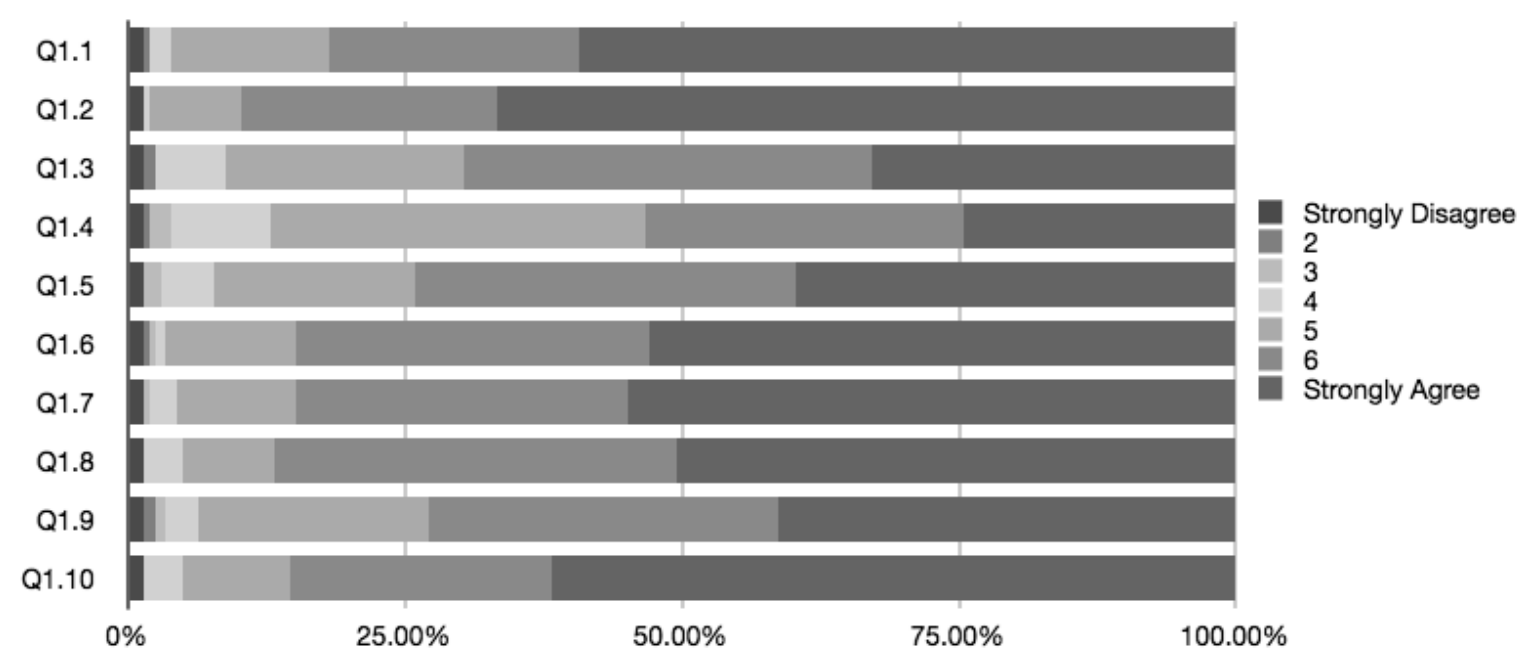

Figure 1: Response Presentation

\section{Comparing the Views of Males and Female Respondents}

In order to compare differences between the views of male and female responses, the means of the responses for each statement were calculated. The percentage differences between the means were calculated to determine statements where male and female respondents differed most; these are depicted in Table 4.

Table 4: Likert Scale Differences between Male and Female

\begin{tabular}{|l|c|c|c|c|}
\hline $\mathbf{N r}$ & Likert Scale Statements & Male & Female & Percentage Difference \\
\hline 1.1 & Good writing skills & 6.2 & 6.39 & $3.02 \%$ \\
\hline 1.2 & Good subject knowledge & 6.36 & 6.58 & $3.40 \%$ \\
\hline 1.3 & Good practical knowledge base & 5.72 & 5.97 & $4.28 \%$ \\
\hline 1.4 & Technological savvy & 5.3 & 5.77 & $\mathbf{8 . 4 9 \%}$ \\
\hline 1.5 & A student centred orientation & 5.81 & 6.13 & $5.36 \%$ \\
\hline 1.6 & Good communication skills & 6.18 & 6.34 & $2.56 \%$ \\
\hline 1.7 & Ability to guide students & 6.09 & 6.46 & $5.90 \%$ \\
\hline 1.8 & Quality consciousness & 6.1 & 6.39 & $4.64 \%$ \\
\hline 1.9 & Ability to apply ODL principles & 5.82 & 6.13 & $5.19 \%$ \\
\hline 1.10 & Fair and ethical behaviour & 6.07 & 6.59 & $\mathbf{8 . 2 1 \%}$ \\
\hline
\end{tabular}

The largest differences in views were for "Fair and ethical behaviour" (1.10), "Technological savvy" (1.4), "Ability to guide students" (1.7), and "A student-centred orientation" (1.5). The means were used to rank the statements from the most important (rank $=1$ the highest mean) to the least important (rank $=10$ the lowest mean). Table 5 shows the ranks for the male and female respondents, respectively. 
Table 5: Male and Female Response Ranking

\begin{tabular}{|c|c|c|c|c|}
\hline $\mathbf{N r}$ & Likert Scale Statements & Overall Rank & Male Ranks & Female Ranks \\
\hline 1.1 & Good writing skills & 3 & 2 & 4 \\
\hline 1.2 & Good subject knowledge & 1 & 1 & 2 \\
\hline 1.3 & Good practical knowledge base & 9 & 9 & 7 \\
\hline 1.4 & Technological savvy & 10 & 8 & 8 \\
\hline 1.5 & A student centred orientation & 8 & 3 & 6 \\
\hline 1.6 & Good communication skills & 5 & 5 & 5 \\
\hline 1.7 & Ability to guide students & 4 & 4 & 3 \\
\hline 1.8 & Quality consciousness & 6 & 7 & 4 \\
\hline 1.9 & Ability to apply ODL principles & 7 & 6 & 6 \\
\hline 1.10 & Fair and ethical behaviour & 2 & & 1 \\
\hline
\end{tabular}

\section{The Top Four Characteristics of an ODL Practitioner}

Taking the responses to the statements for the 10 Likert scale questions into account, the top four characteristics of an ODL practitioner are considered "Good subject knowledge" (1.2), "Fair and ethical behaviour" (1.10), "Good writing skills" (1.1), and "Ability to guide students" (1.7).

The frequency chart (Figure 2) shows the ranking of the statements visually.

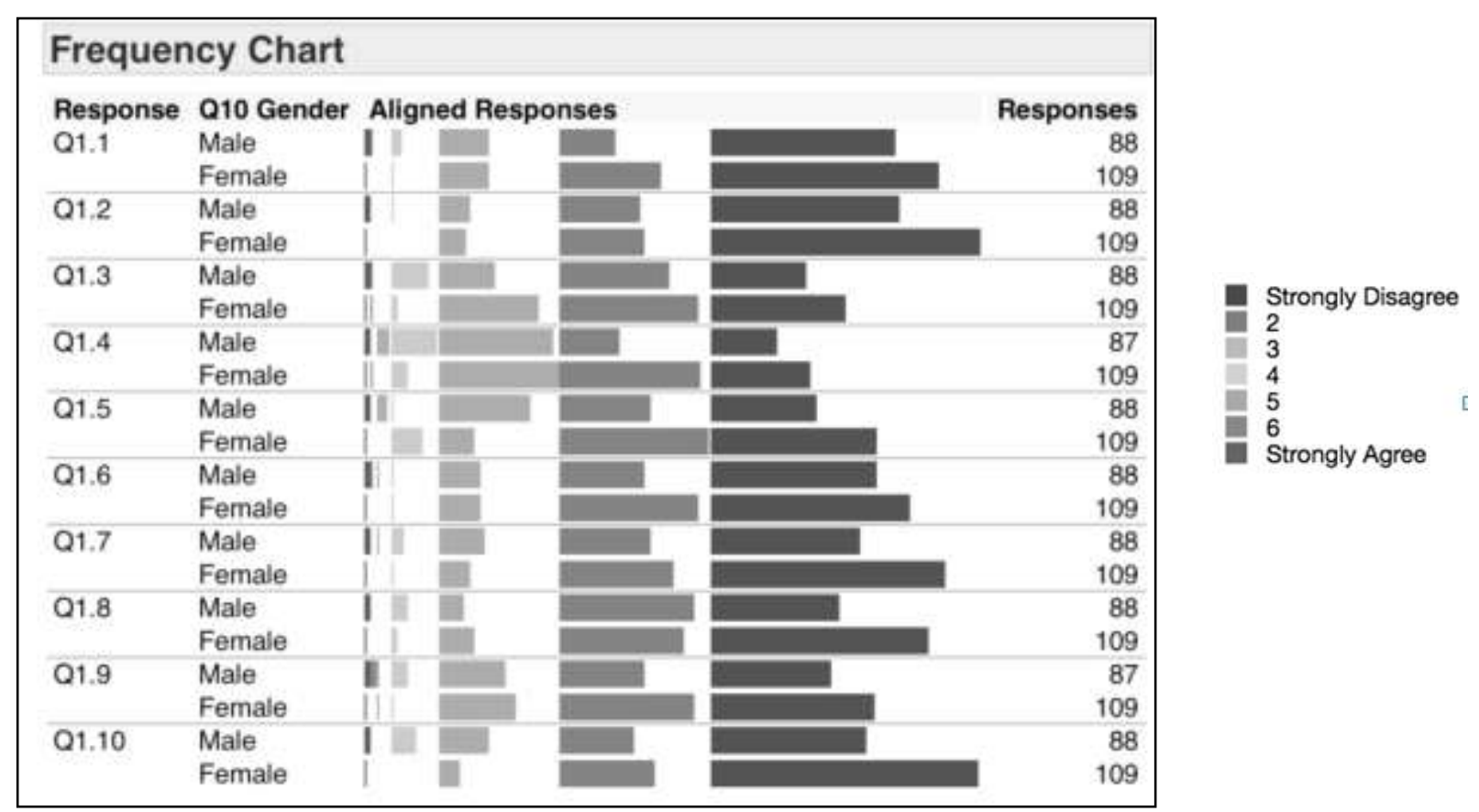

Figure 2: Male and Female Rankings of Statements: The Difference in View between Males and Females on the Characteristics of an ODL Practitioner

To test for a significant difference between the responses of the male and female respondents for the characteristics statements, a non-parametric Wilcoxon Rank Sum test is used. Table 6 shows only the significant results of the Wilcoxon Rank Sum tests.

Table 6: Wilcoxon Rank Sum Tests

\begin{tabular}{|l|c|c|c|c|}
\hline \multicolumn{1}{|c|}{ Nr } & Characteristic & Z-value & P-value & Significance \\
\hline 1.4 & Technological savvy & -3.39 & 0.0007 & Highly significant \\
\hline 1.5 & A student centred orientation & -2.55 & 0.0106 & Significant \\
\hline 1.7 & Ability to guide students & -2.475 & 0.0133 & Significant \\
\hline 1.10 & Fair and ethical behaviour & -3.87 & 0.0001 & Highly significant \\
\hline
\end{tabular}


These analyses revealed a significant difference between rank characteristics scores observed for the male and female respondents. The rank sums of the female respondents were significantly higher than the male respondents for "Technological savvy" (1.4), for "A student-centred orientation" (1.5), for "Ability to guide students" (1.7), and "Fair and ethical behaviour" (1.10), indicating that females consider them more important than males do.

\section{The Difference in View between Age-Groups on the Characteristics of an ODL Practitioner}

To test for a significant difference between the responses of the age-groups of the respondents for the characteristics statements, a non-parametric Kruskal-Wallis test is used. The age-groups were recoded into the following categories: 35 years old and younger (92), between 36 and 50 years of age (66), and 51 years and above (40).

Table 7 shows only the significant results of the Kruskal-Wallis tests.

Table 7: Kruskal-Wallis Tests

\begin{tabular}{|l|c|c|c|c|c|}
\hline \multicolumn{1}{|c|}{$\mathbf{N r}$} & Characteristic & DF & Chi-Square value & P-value & Significance \\
\hline 1.5 & A student centred orientation & 2 & 5.16 & 0.0756 & Significant at $90 \%$ \\
\hline 1.6 & Good communication skills & 2 & 6.62 & 0.0364 & Significant \\
\hline 1.10 & Fair and ethical behaviour & 2 & 12.98 & 0.0015 & Highly significant \\
\hline
\end{tabular}

The frequency chart (Figure 3) gives a visual representation of the responses.

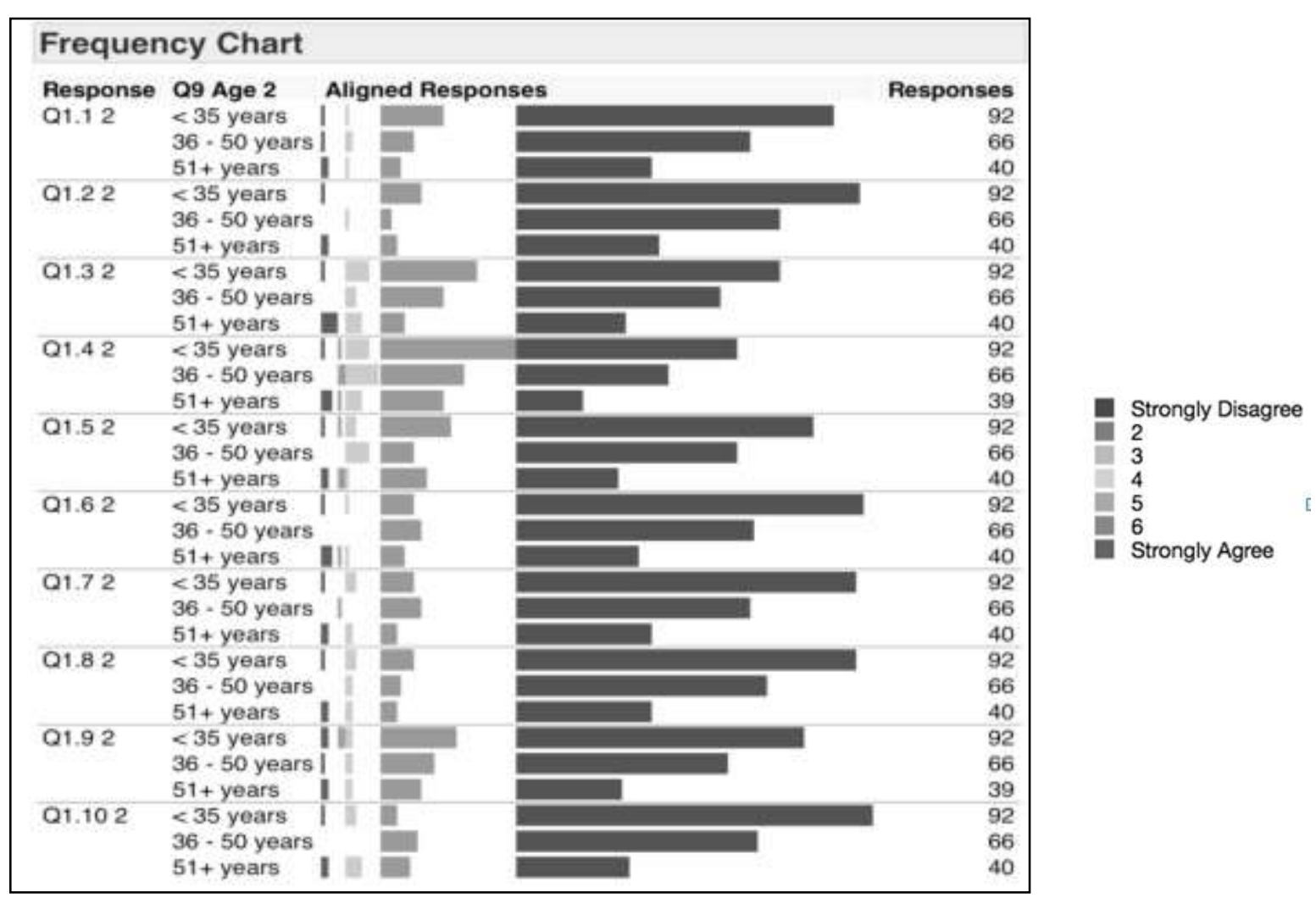

Figure 3: Male and Female Rankings of Statements - The Difference in View between Males and Females on the Characteristics of an ODL Practitioner 


\section{RECOMMENDATIONS}

The results of the survey reported that the top two characteristics are "Good subject knowledge" and "Fair and ethical behaviour". This means that when an ODL institution considers hiring a new ODL practitioner, the subject knowledge of the applicant should be tested. This is evident in the publications list provided by the applicants, but also the more emotive characteristics should be evaluated. There should be some attempt to measure the emotional quotient around the possession of fair and ethical attributes within the applicant, something that is not evident in a CV, and which needs to be developed and tested to apply in the interview of applicants for an ODL post. One should bear in mind that the initial list used in the empirical study was generated from a Delphi technique with some very experienced university lecturers and ODL practitioners. Although the list shows some characteristics that seem fairly obvious, there are others which are not often tested for in an evaluation of potential candidates, such as being quality conscious. Again, the methods used to evaluate and rank potential applicants need to be reviewed to see whether the processes used in the evaluative tests actually attempt to judge applicants based on these characteristics. Lastly, it also implies that current ODL practitioners need to manage their own skill set, as the characteristics are dynamic and change over time. The ODL practitioner needs to ensure that their own CV reflects the characteristics that are considered important, and show that those have been encompassed and addressed within the current set of competencies and skills listed in the CV.

Another important implication is the clear and distinct differences in terms of the criteria between the male and female respondents. This means that an ODL institution cannot follow a "one size fits all" programme with its entire staff, but needs to take these differences into account in terms of the recruitment, evaluation and training of its staff. The different departments need to do a more personal evaluation of each staff member to see where their opinions lie and to work out a more individualistic programme for each. This also means that the department heads need to be better trained as managers to be able to deal with the differences with staff members. The department heads should also create development programmes that take these differences into account and which still strive for the generic goal of academic excellence cumulating from the individual development journeys of the staff members. Sexism still exists in the workplace and academic environments are not immune to this, so the management structures need to be sensitised toward these subtle differences between the sexes in terms of opinions and characteristics for success.

There is also a need to sensitise the academic leadership staff of departments to the differences exhibited with the age cohorts. The results again showed clear differences in terms of the characteristics across the age cohorts. This may be as a result of the older staff members being more exposed to the practicalities of the job, and thus less "idealistic" toward the more emotional characteristics, but again it highlights that a "one size fits all" approach is not effective. Care must be taken to ensure all age cohorts are motivated, emotionally engaged in the job, and skilled in practical aspects to be effective. The older members could perhaps be targeted in more motivational development to keep the skill and attitudinal levels where they should be to have effective staff members. Many institutional work environments lean more toward mechanistic work and culture paradigms, and here the academic leadership should make efforts to ensure there is a strong idealistic and effective culture in the departments under which the individual staff members can all flourish.

As before, the implications are that the academics making evaluative decisions with respect to staff members, and who lead the departments in ODL institutions, need to be better trained to take these differences in terms of sex and age into account.

\section{CONCLUSION}

The objectives of the research study were to investigate the characteristics that a good open distance learning practitioner should possess, by investigating the important characteristics of a good ODL practitioner, also whether there are differences between the views of male and female ODL practitioners and between different age cohorts.

The investigation found that all the characteristics were considered as important by the respondents - both male and female. Considering the averages (for ranking purposes), good subject knowledge and fair and ethical 
behaviour were considered as the two most important characteristics of a good ODL practitioner, whereas good writing skills, ability to guide students, good communication skills, and quality consciousness were considered to be less important by the respondents.

By taking the responses of the statements for the 10 Likert scale questions into account, it was found that the top four characteristics of a good ODL practitioner are considered to be good subject knowledge, fair and ethical behaviour, good writing skills, and the ability to guide students. It was further evident that the rank sums of the female respondents were significantly higher than the male respondents for technological savvy, for having a student-centred orientation, for the ability to guide students, and for being fair and ethical, indicating that females consider it as being more important than males. The implications, for this study, are that universities may use the information obtained as a basis for further studies. The results may also help ODL institutions to identify the characteristics they should be looking for when appointing ODL practitioners.

\section{AUTHOR INFORMATION}

Professor Michael C. Cant is the Head of the Department of Marketing and Retail Management at the University of South Africa (UNISA). He has published over 40 accredited articles in refereed journals and is the editor and author of more numerous textbooks in marketing. These books are widely prescribed at universities in South Africa. $\mathrm{He}$ has presented papers at more than 45 international conferences all over the world and is a well respected marketing and retail scholar. He holds a DCom in Marketing from the University of South Africa. E-mail: cantmc@unisa.ac.za (Corresponding author)

Professor Johannes A. Wiid is a Professor in the Department of Marketing and Retail Management at the University of South Africa (UNISA). He has published numerous articles in refereed journals and is the editor and author of various textbooks in marketing. These books are widely prescribed at universities in South Africa. He holds a DCom in Marketing from the University of Johannesburg. E-mail: jwiid@unisa.ac.za

Ricardo Machado is a senior lecturer in the Department of Marketing and Retail Management at the University of South Africa (UNISA). He holds a BSc from the University of Tulsa, and an MBA in Finance from the University of Colorado. Richardo is the author or co-author of more than 25 books in marketing, with extensive experience in executive education in the fields of retailing, financial services, construction, automotive and FMCG industries. He is also a former marketing executive for a multinational food and beverage company. E-mail: machar@unisa.ac.za

\section{REFERENCES}

1. Ackerman, DS \& Hu, J. (2011). Effect of type of curriculum on educational outcomes and motivation among marketing students with different learning styles. Journal of Marketing Education, 33(3): 273-284.

2. Bacellar, FCT \& Ikeda, AA. (2006). Marketing lecturers: paths and perspectives. European Business Review, Vol. 18(3): 231-242.

3. Bates, AW. (1997). The impact of technological change on open and distance learning. Distance Education, 18(1): 93-109.

4. Bradley, N. (2010). Marketing research: tools and techniques. $2^{\text {nd }}$ ed. New York: Oxford University Press.

5. Brown, N. (2004). What makes a good educator? The relevance of Meta programmes. Assessment \& Evaluation in Higher Education, 29(5), 515-533.

6. Charbonneau, L. (2012). Students Prefer Good Lecturers Over the Latest Technology in Class. [Online]. Available from: http://www.universityaffairs.ca/students-prefer-good-lectures-over-the-latest-technologyin-class.aspx. Accessed on 2013.02.22

7. Desai, S. Damewood, E \& Jones, R. (2001). Be a good teacher and be seen as a good teacher. Journal of Marketing Education, 23(2), 136-143.

8. Ekroth, L. (n.d). Why Professors Don't Change. Essays on Teaching Excellence [Online]. Available from: http://www.podnetwork.org/publications/teachingexcellence/89-90/V1,\%20N8.pdf Accessed on 2012.03.05 
9. Elliot, C. (n.d). Some Things Don't Change: The Global Draw of American Higher Education. The evoLLLution [Online]. Available from: http://www.evolllution.com/opinions/some-things-dont-changethe-global-draw-of-american-higher-education/. Accessed on 2012.03.06

10. Ferrarri, J. (2012). Schools Boss Calls for Right Teachers, Right Skills. National Affairs [Online]. Available from: http://www.theaustralian.com.au/national-affairs/education/schools-boss-calls-for-rightteachers-right-skills/story-fn59nlz9-1226352471009. Accessed on 2012.02.21.

11. Fiedler, M \& Welpe, I. (2008). Appointment preferences of management lecturers. Schmalenbach Business Review, 60: 4-31.

12. Forsyth, H. Pizzica, J. Laxton, R \& Mahony, M. (2010). Distance education in an era of eLearning: challenges and opportunities for a campus-focused institution. Higher Education Research and Development, 29(1) 15-28. [Online]. Available from: http://www.tandfonline.com/ doi/pdf/10.1080/07294360903421350. Accessed on 2012.11.13.

13. Galusha, JM. (1998). Barriers to Learning Distance Education. [Online] Available from: http://www.eric.ed.gov/PDFS/ED416377.pdf. Accessed on 2013.02.21.

14. Ghaith, G. (2010). An exploratory study of the achievement of the twenty-first century skills in higher education. Education + Training, 52(6): $489-498$.

15. Gottschalk, T. H. (n.d). Distance Education at a Glance. University of Idaho: Engineering Outreach. [Online]. Available from: http://www.uiweb.uidaho.edu/eo/dist1.html. Accessed on 2013.02.21.

16. Gruber, T. Reppel, A \& Voss, R. (2010). Understanding the characteristics of effective lecturers: the student's perspective. Journal of Marketing for Higher Education, 20(2): 175-190.

17. Gruber, T. Lowrie, A. Brodowsky, GH, Reppel, AE. Voss, R \& Chowdhury, I. (2012). Investigating the influence of lecturer characteristics on student satisfaction and dissatisfaction: a comparative study. Journal of Marketing Education, 34(2): 165-178.

18. Harper, D. (n.d). Online Etymology Dictionary. [Online]. Available from: http://www.etymonline. com/index.php?search=Lecturer\& searchmode=none. Accessed on 2012.11.12.

19. Henning, JC. (2010). Management of open distance libraries with reference to learner support. Library Management, 31(6): 440-450.

20. Hickman, KA \& Shrader, MJ. (2000). Predicting the Research Productivity of New Finance Lecturers. Financial Practice and Education, Spring/Summer, 93-98.

21. Hill, Y. Lomas, LL \& MacGregor, J. (2003). Students' perceptions of quality in higher education. Quality Assurance in Education, 11(1), 15-20.

22. Husbands, CT. (1998). Implications for the assessment of the teaching competence of staff in higher education of some correlates of student' evaluations of different teaching styles. Assessment \& Evaluation in Higher Education, 23(2), 117-139.

23. ICEF. (2012). Students demanding more technology in education. [Online]. Available from: http://monitor.icef.com/2012/10/students-demanding-more-technology-in-education. Accessed on 2012.03.07.

24. IEASA. (n.d). In Leaps and Bounds: Growing Higher Education in South Africa. [Online]. Available from: http://www.ieasa.studysa.org/resources/Study_SA 11/In\%20leaps\%20and\%20bounds\%20 Growing.pdf. Accessed on 2012.03.07.

25. Ingram, D. (2003). James Watt's Centrifugal Governor. The Caius Engineer, 14(2). [Online]. Available from: http://babylon.acad.cai.cam.ac.uk/students/study/engineering/engineer031/ celecturer.htm. Accessed on 2012.11.12.

26. Kheiri, S. (2012). Identifying and comparing philosophical schools of lecturers about educational programs in Islamic Azad University, Abhar Branch. Procedia - Social and Behavioural Sciences, 45: 2801-2805.

27. Lammers, WJ \& Murphy, JJ. (2002). A profile of teaching used in the university classroom: a descriptive profile of a US Public University. Active Learning in Higher Education, 3:54-67. [Online]. Available from: http://alh.sagepub.com/content/3/1/54. Accessed on 2012.08.29.

28. London Deanery. (2012). What Makes a Good Lecturer? [Online] Available from: http://www.faculty.londondeanery.ac.uk/e-learning/improve-your-lecturing/what-makes-a-good-lecturer. Accessed on 2012.03.05. 
29. Lovitt, CR. (n.d). How Universities are Changing... for the Better. Central Connecticut State University [Online]. Available from: http://www.ccsu.edu/uploaded/departments/Administrative Departments/Academic Affairs/Provost's Presentations Op-Eds/Improving_How Students Learn.pdf. Accessed on 2012.03.05.

30. Maslen, G. (2012). Universities will face uncertain future without radical overhaul. University World News [Online]. Available from: http://www.universityworldnews.com/article.php?story=20121024 084857770 . Accessed on 2012.03.07.

31. McDonald, C \& Gates, R. (2010). Marketing Research Essentials. $7^{\text {th }}$ ed. Hoboken, New Jersey: John Wiley \& Sons.

32. McElwee, G \& Redman, T. (1993). Upward appraisal in practice. Education + Training, 35(2), 27-31.

33. Meier, HH \& Kamath, R. (2005). A multidimensional investigation of named lectureships in Accounting: 2002-2003. Journal of Education for Business, 80: 295-301.

34. Olson, T \& Einwohner, RL. (2001). Forming and transforming the teaching self in different institutional environments: Two teachers' experiences. Teaching Sociology, 29, 403-422.

35. Onike, R. (2010). Teacher as a key factor affecting learning [Online]. Available from: http://searchwarp.com/swa596810-Teacher-As-A-Key-Factor-Affecting-Learning.htm [Accessed: 2013.02.21].

36. Oxford Online Dictionary. (n.d). Definition of Lectureship [Online]. Available from: http://oxforddictionaries.com/us/definition/american english/lectureship. Accessed on 2012.03.07.

37. Paswan, AK \& Young, JA. (2002). Student evaluation of instructor: A nomological investigation using structural equation modeling. Journal of Marketing Education, 24(3), 193-202.

38. Roberts, D. (n.d). Learner support in South African distance education: a case for action. [Online]. Available from: http://www.col.org/pcf3/Papers/PDFs/Roberts_Des.pdf. Accessed on 2012.11.08.

39. Samans, JC. (n.d). The impact of web-based technology on distance education in the United States. [Online]. Available from: http://www.nyu.edu/classes/keefer/waoe/samans.html. Accessed on 2012.11.08.

40. Serow, RC. (2000). Research and teaching at a research university. Higher Education, 40, 449-463.

41. Shah, S. (n.d). Impact of Teachers' Behaviour on the Academic Achievement of University Students. [Online]. Available from: http://prr.hec.gov.pk/Thesis/293S.pdf. Accessed on 2013.02.22.

42. Smart, DT. Kelley, CA \& Conant, JS. (2003). Mastering the art of teaching: Pursuing excellence in a new millennium. Journal of Marketing Education, 25(1), 71-78.

43. Swanson, SR. Frankel, R \& Sagan, M. (2005). Exploring the impact of cultural differences. Marketing Education Review, 15(3), 37-48.

44. SWAP. (2008). What Makes a Good Lecturer? The Student's Perspective. [Online]. Available from: http://www.swap.ac.uk/docs/swapguide_4b.pdf. Accessed on 2013.02.22.

45. Pozo-Munoz, C. Rebolloso-Pacheco, E \& Fernandez-Ramirez, B. (2000). The 'Ideal Teacher'. Implications for student evaluation of teacher effectiveness. Assessment \& Evaluation in Higher Education, 25(3), 253263.

46. Ukpokodu, ON. (2008). Teachers' reflections on pedagogies that enhance learning in an online course on teaching for equity and social justice. Journal of Interactive Online Learning, 7(3): 227-255. [Online]. Available from: http://www.ncolr.org/jiol/issues/pdf/7.3.5.pdf. Accessed on 2012.11.13.

47. UNESCO. (2003). What is Open Distance Learning? [Online] Available from: http://portal.unesco.org/education/en/ev.php-URL_ID=22329\&URL_DO=DO_TOPIC\&URL SECTION=201.html. Accessed on 2012.05.03.

48. UNICEF. (2000). Defining Quality in Education. [Online]. Available from: http://www.unicef.org/ education/files/QualityEducation.PDF. Accessed on 2013.02.21.

49. UNISA. (2012). Prof Zodwa Dlamini has been nominated by the Department of Health to serve on the Scientific Advisory Committee of the Department of Science and Technology. [Online]. Available from: http://staff.unisa.ac.za/index.jsp?link=http://staff.unisa.ac.za/e-connect/e-notice/2012/09/11/prof-zodwadlamini-has-been-nominated-by-the-department-of-health-to-serve-on-the-scientific-advisory-committeeof-the-department-of-science-and-technology/ Accessed on 11.09.2012.

50. University of Minnesota. (2012). Writing your teaching philosophy. [Online]. Available from: http://www1.umn.edu/ohr/ teachlearn/tutorials/philosophy/index.html. Accessed on 2012.11.07. 
NOTES 